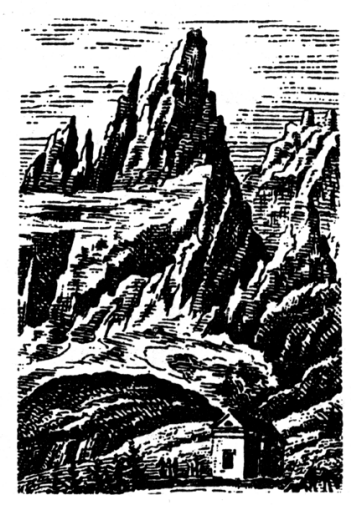

\title{
Małgorzata Misiak
}

Uniwersytet Wrocławski

malgorzata.misiak@uwr.edu.pl

DOI: $10.19195 / 2084-4107.11 .19$

\section{Na kołpaku gór - rzecz o temkowskiej tożsamości}

Słowa-klucze: Beskidy, Łemkowie, język, literatura

Keywords: Beskid Mountains, Lemkos, language, literature

\section{On the calpack of the mountains - or Lemko identity}

\section{Summary}

The paper refers to the bilingual, Polish-Lemko, collection of poems by Władysław Graban, Na kotpaku gór (On the Calpack on the Mountains), published in 1991. The mountains, the Beskids, the Lemkos' homeland, are presented as the exotic calpack, a type of cap made of several pieces of fabric sewn together. The analysis is based on the assumption that the Lemkos' identity has been shaped like a calpack, sewn together from various cultural, religious and linguistic elements as a result of cultural transgressions - complex in their course and stretched over time. In the successive parts of the article the author discusses the various components of the ethnic identity of this minority, little known to the public at large. 
Бо лемківси гори

Долини прекрасни

Не мож вас забыти

Ні в біді, ні вщасті ${ }^{1}$.

W 1991 r. w krakowskiej oficynie Miniatura ukazał się dwujęzyczny polsko-łemkowski tomik wierszy łemkowskiego poety Władysława Grabana pod tytułem Na kotpaku gór [На ковпаку гip]. Znalazły się w nim 54 wiersze, które jak „Mgielne tabuny / obręczą spięły grzbiety gór”2. Góry porównane zostały w tomiku do „wysokiej czapki [...] w kształcie stożka, futrzanej lub obszytej futrem”, zrobionej „ze zszytych z sobą, zwężających się ku górze klinów”4. Góry przypominające kołpak - egzotyczne, na co wskazuje tureckie źródło terminu, nakrycie głowy. A przecież chodzi o polskie Beskidy — niewysokie, przyjazne, swojskie, choć w pewien sposób jednak egzotyczne, bo chociażby z wtopionym w krajobraz najbardziej charakterystycznym, i to niepolskim, ich elementem łemkowskimi cerkiewkami. W całym tomiku nie pojawia się słowo „kołpak”, w żadnym wierszu nie ma metafory odwołującej się do tego porównania, gdyż wszystkie Grabanowe wiersze powstały na kołpaku gór i wszystkie składają się na ów kołpak, przynoszą próbę odpowiedzi na pytanie, co to znaczy być Łemkiem.

$\mathrm{Na}$ kołpaku tych gór ukształtował się byt etnicznie odmienny od polskiego — Łemkowie - niczym pozszywane kawałki materii kołpaku, każdy inny, ale wszystkie niezbędne, aby powstało nakrycie głowy. Każdy fragment materiału ma inny wzór, każdy oddzielony jest od drugiego i zarazem połączony z nim grubym, mocnym ściegiem. Tożsamościowy łemkowski kołpak został solidnie uszyty przez historię. Swiadectwem tego są sami Łemkowie - trwający uparcie wbrew wypadkom dziejowym i wciąż świadomie sięgający do elementów, z których powstał ich tożsamościowy kołpak.

Łemkowszczyzna etniczna, ich ojczyzna, jest dziś kategorią historyczną. Została przymusowo zamieniona na obczyznę w wyniku akcji wysiedleńczych z lat 1944-1946 i następnie w 1947 r. ${ }^{5}$ Łemkowie znaleźli się poza Łemkowszczyzną, z dala od swoich gór. Ze skonsolidowanej społeczności stali się grupą

${ }^{1}$ Łemkowska piosenka ludowa. Zob. Piosenki łemkowskie i ukrainskie, pomysł, wklepanie i skład: W. Chemijewski „Żaba”, Warszawa 2001, s. 55.

2 W. Graban, Jesienny trzmiel, [w:] idem, Na kotpaku gór, Kraków 1991, s. 6.

${ }^{3}$ Kolpak, [hasło w:] Słownik języka polskiego PWN, http://sjp.pwn.pl/sjp/kolpak;2472469. html (dostęp: 12.10.2016).

${ }^{4}$ Kolpak, [hasło w:] Encyklopedia powszechna PWN, t. 2,Warszawa 1984, s. 518.

${ }^{5}$ Chodzi o przeprowadzone po II wojnie światowej przez ówczesne władze polityczne akcje przesiedleńcze ludności wschodniosłowiańskiej zamieszkującej na terytorium Polski. Pierwsza z nich miała miejsce w latach 1944-1946. Według szacunków wówczas w ramach umowy między radziecką Ukraińską Republiką Rad a PKWN o wymianie ludności pasa nadgranicznego wyjechało na Ukrainę około 60\% ogółu ludności rusińskiej. Pozostała ludność w wyniku przeprowadzonej w 1947 r. akcji „Wisła” została przesiedlona na obszar tzw. ziem odzyskanych, województw północnych i zachodnich. Zob. E. Misiło, Repatriacja czy deportacja. przesiedlenie Ukraińców z Polski do 
o charakterze diasporowym. Dziś zamieszkują głównie na ziemiach zachodniej i północnej Polski.

Beskidy - góry różnych granic. $Z$ jednej strony tych nieodmiennie trwających, bo etnicznych, z drugiej - ulegających ciągłym przesunięciom granic politycznych. Beskidy, pasmo Karpat, które stało się przestrzenią umożliwiającą spotkanie kultury Słowian zachodnich (Polaków, Słowaków) ze wschodnimi (Rusinami). W wyniku wielowiekowego sąsiedztwa na pograniczu terytorialnym ${ }^{6}$ wytworzyło się specyficzne pogranicze etniczno-kulturowe, doszło do przeniknięcia cech kultury i języka. Beskidzkie pogranicze interakcyjne powstało jako wynik transgresji kulturowych, skomplikowanych w przebiegu i rozciągniętych w czasie. Należy podzielić w tym wypadku opinię Jerzego Nikitorowicza, dla którego wystarczającym warunkiem istnienia pogranicza interakcyjnego jest fakt istnienia wśród członków danej społeczności chęci zauważenia, zaakceptowania istnienia i chęci poznania innej, odmiennej społeczności. Stanowi to warunek podjęcia dialogu między grupami. Przy czym wspólnoty wchodzące w interakcję mogą charakteryzować się zupełną odmiennością kulturową, brakiem podobieństwa językowego lub obyczajowego. Nie jest również konieczne istnienie jakiejkolwiek wspólnej przeszłości

Do 1772 r. całe Beskidy przynależały do I Rzeczypospolitej. Południowe stoki Karpat zaś znajdowały się w obrębie Królestwa Węgier. Trzeba pamiętać, że ówczesne granice polityczne nie przeszkadzały w swobodnym przemieszczaniu się ludności na tym obszarze. Sytuację zmieniła doba rozbiorowa, kiedy teren ten znalazł się pod panowaniem Habsburgów, pozostając w obrębie jednego tworu państwowego. Rozpad czarno-żółtej monarchii w 1918 r. sprawił, że granice państwowe skutecznie przedzieliły omawiany teren. $Z$ jednej strony Rusini polscy, Łemkowie, stali się obywatelami Państwa Polskiego, z drugiej - Rusini z południowych stoków Karpat stali się obywatelami nowopowstałej Republiki Czechosłowackiej ${ }^{8}$. Dziewiętnastowieczny brak granic państwowych umożliwiał pełnowymiarową transgresję. Ich pojawienie się w znacznym stopniu ograniczyło ten proces. Łemkowie, Rusini z północnych stoków Karpat, przez stulecia wędrowali w kierunku południowym, na Słowację i na Nizinę Węgierską, w poszukiwaniu pracy zarobkowej, w celach handlowych, religijnych czy towarzyskich. Można ich było spotkać na jarmarkach w Tyliczu, Bardejowie czy Starej Lubowni; maziarze z Łosia oferowali maź, a Łemkowie z Kunkowej — produkty wykonane

USRR 1944-1946, t. 1. Dokumenty 1944-1945, Warszawa 1996; t. 2. Dokumenty 1946, Warszawa 1999; Akcja ,,Wisła”. Dokument i materiaty, wybór, wstęp i opracowanie E. Misiło, Warszawa 2012.

${ }^{6}$ Jerzy Nikitorowicz definiuje pogranicze terytorialne jako obszar, na którym zamieszkują przedstawiciele co najmniej dwóch grup kulturowych. Zob. idem, Edukacja regionalna na pograniczach, [w:] Edukacja regionalna, red. A.W. Brzezińska, A. Hulewska, J. Słomska, Warszawa 2006, s. 94-95.

7 Ibidem, s. 97-98.

8 Rusini zamieszkujący na Słowacji, tzw. Rusini Preszowszczyzny, wraz z Łemkami stanowią jedną grupę etnograficzną. Jednak nazwę ,Łemkowie” przyjęło się stosować jedynie do Rusinów zamieszkałych w Polsce. Na Słowacji był to etnonim słabo rozpowszechniony. 
z drewna. Na południu poszukiwani byli cieśle z Galicji ${ }^{9}$. Jak pisze Roman Reinfuss, w czasie dużych jarmarków odbywały się również odpusty, jak np. w Lewoczy, gdzie przy okazji handlowano wołami. Rusińscy wyznawcy kościoła rytu wschodniego uczestniczyli także w odpustach organizowanych przez rzymskich katolików ${ }^{10}$. Nie można pominąć również kontaktów rodzinno-towarzyskich. Wszelkie spotkania owocowały zapożyczeniami elementów kultury i obyczajów.

Wróćmy jednak do Grabanowej metafory Beskidów i przyjrzyjmy się materiom, które złożyły się na łemkowski tożsamościowy kołpak.

\section{Materia pierwsza — etniczność}

Z tumanu wieków / święty Roman / pędzi kolejne stado / Wołochów 3 туману віків / Святий Роман / Волохів отару іщь єдну / Жене ${ }^{11}$.

Łemkowie, mieszczący się współcześnie w trzech procentach odmienności - jak metaforycznie Łukasz Kaźmierczak nazywa procentowy udział mniejszości narodowych i etnicznych w społeczeństwie Polski ${ }^{12}$ - jako grupa etnograficzna w pełni ukształtowali się $\mathrm{w}$ długim procesie historycznym na terenie pasma Karpat polskich. Rozpowszechniony wśród polskich uczonych pogląd na temat ich etnogenezy (tzw. teoria migracyjna lub wołosko-ruska) ${ }^{13}$ zakłada, że na terenie późniejszej Łemkowszczyzny doszło do nałożenia się na miejscowe, nieliczne osadnictwo polskie kilku fal osadnictwa wołosko-ruskiego. Teorię tę

9 T. Mazurek, Charakter kontaktów transgranicznych między polskimi a stowackimi Rusinami - przeszłość, teraźniejszossć, przyszłość, „Prace Geograficzne” 2009, z. 121, s. 237-247.

10 Zob. R. Reinfuss, Zwiąki kulturowe po obu stronach Karpat w rejonie Łemkowszczyzny, [w:] Łemkowie w historii i kulturze Karpat, red. J. Czajkowski, Rzeszów 1992.

11 W. Graban, Do świętych, [w:] idem, op. cit., s. 16, 37.

12 Ł. Kaźmierczak, Trzy procent odmienności, https://opoka.org.pl/biblioteka/P/PS/trzy_procento.html (dostęp: 20.05.2015). Jest to odniesienie do wyników ostatniego powszechnego spisu ludności z 2011 r. (97,09\% zadeklarowało narodowość polską). Wyniki Narodowego Spisu Powszechnego Ludności i Mieszkań 2011 - mniejszości narodowe i etniczne oraz język regionalny, http://mniejszosci.narodowe.mswia.gov.pl/mne/mniejszosci/wyniki-narodowego-spis (dostęp: 12.10.2016).

${ }^{13}$ Leszek Filipiak wyodrębnia trzy główne teorie na temat etnogenezy Łemków, określając je z punktu widzenia środowisk, w których powstały i są rozpowszechnione: polską (teoria migracyjna, teoria wołosko-ruska), łemkowsko-rusińską (tzw. teoria autochtonizmu) i ukraińską. Według teorii autochtonizmu Łemków mieliby być oni potomkami plemienia Białych Chorwatów zamieszkujących na terenie Karpat. Stanowisko ukraińskie uważa Łemków za potomków Rusinów/ Ukraińców zamieszkujących interesujące tereny w czasach Rusi Kijowskiej, czyli już w XII w. Badania archeologiczne Karpat polskich nie potwierdzają jednak słuszności dwóch ostatnich teorii. Osadnictwo na obszarze Łemkowszczyzny etnicznej jest potwierdzone dopiero od XIII w. Zob. idem, Społeczno-polityczna sytuacja Łemków w III RP, Toruń 2013, s. 54-59. Por. także M. Misiak, Etnogeneza w świetle badań naukowych, [w:] eadem, Łemkowie. W kręgu badań nad mniejszościami etnolingwistycznymi w Europie, Wrocław 2006, s. 45-54.

Góry, Literatura, Kultura 11, 2018

(C) for this edition by CNS 
przedstawił w latach trzydziestych XX w. Kazimierz Dobrowolski ${ }^{14}$. Prowadzący koczowniczy tryb życia Wołosi pojawili się w Karpatach już w XIV w. Wędrując wzdłuż grzbietów górskich, wchłaniali miejscową ludność. Na teren Karpat polskich dotarły już grupy, które w swym składzie etnicznym miały przewage elementu ruskiego ${ }^{15}$. Jak pisał K. Dobrowolski, na terenie Łemkowszczyzny „,poważna część pierwotnych nazwisk (w niektórych okolicach 1/5-1/3) wykazuje pochodzenie bałkańsko-rumuńsko-ruskie"16. Analiza materiału antroponimicznego nastręcza jednak trudności. Często mamy do czynienia z imionami skróconymi, co powoduje, że budzi dużo wątpliwości wskazanie właściwej dla nich podstawy słowotwórczej. Należy pamiętać, że niejednokrotnie rumuńscy Wołosi nosili imiona chrześcijańskie w wersji bizantyjskiej, które z tego względu mogą być interpretowane jako ruskie. Niewątpliwie zaś rumuńsko-bałkańskie pochodzenie językowe charakteryzuje liczne tamtejsze nazwy topograficzne, takie jak np.:

potok Strunżana w Bereście — od strunga 'bramka w koszarze' góra Kornuty koło Przegoniny — od kornuta 'owca z rogami' góra Fereczaty — na południowy zachód od wsi Smerek, od rum.ferece 'paproć' 'wilcza jagoda'

góra Matragona — między Solinką a Maniowym, od rum. mătrăgună Reped, potem Rzepedź — potok i wieś, od rum. répete 'szybki' 17 .

Janusz Rieger wymienia również szereg nazw wsi na Łemkowszczyźnie wskazujących na pochodzenie etniczne ich mieszkańców (ale trzeba zaznaczyć, że może to też być wskazanie na typ prawa lokacyjnego), np. Królowa Ruska (dziś: Królowa Górna), Trzciana Wałaska (dziś: Trzciana), Uście Ruskie (dziś: Uście Gorlickie).

Łemkowie to egzoetnonim o charakterze przezwiskowym, a więc nazwa narzucona tej ludności przez inną, sąsiednią, ale „obcą” grupę. Przyjmuje się, że nazwa powstała na pograniczu łemkowsko-bojkowskim w pierwszej połowie XIX w., w piśmiennictwie pojawiła się już w dziewiętnastowiecznych opisach etnograficznych ${ }^{18}$. Etnikon ten motywowany jest słowem lem ('tylko, lecz, jeno'),

${ }^{14}$ K. Dobrowolski, Migracje wołoskie na ziemie polskie, [w:] Pamiętnik V Powszechnego Zjazdu Historyków Polskich w Warszawie, 29 listopada do 4 grudnia 1930 r., Lwów 1930, s. 135152.

15 Z. Szanter, Z przeszłości Łemkowszczyzny. Dzieje Przysłopia i Nowicy, Warszawa 2013, s. 22.

16 K. Dobrowolski, op. cit., s. 150.

17 J. Rieger, Stownictwo i nazewnictwo temkowskie, Warszawa 1995, s. 177.

18 Po raz pierwszy w 1820 r. w pracy czeskiego etnografa Jana Čaploviča pt. Etnografické pozorowania $z$ Uherska. Nazwa ta w tytule pojawiła się po raz pierwszy w pracy Aleksija J. Torońskiego Русинь-Лсмки, „Зоря Галицкая” яко альбум на год 1860, Lwów 1860, s. 389-428. Do spopularyzowania etnonimu w piśmiennictwie naukowym mógł się przyczynić Oskar Kolberg, którego dzieło Sanockie-Krośnieńskie (tytuł roboczy brzmiał Sanockie-Łemki) zawierał obszerny opis etnograficzny Łemków. Zob. O. Kolberg, Dzieła wszystkie, t. 49. Sanockie-Krośnieńskie, cz. 1, red. A. Skrukwa, 
który nie jest spotykany ani w gwarze bojkowskiej, ani huculskiej — gwarach sąsiadujących z Łemkami grup górali ruskich. Dziewiętnastowieczny ruski lingwista, Aleksy Torońskij, w etnograficznym opisie Łemków z 1860 r. potwierdza, że poza nimi żadna $\mathrm{z}$ grup Rusinów nie miała tego słowa w swoim zasobie leksykalnym. Łemkowie zapożyczyli ów wyraz z dialektów słowackich. W przekonaniu sąsiadów używali oni tego leksemu z nadmierną, a więc zwracającą uwagę i będącą źródłem żartów, częstotliwością. W wydanym już w XX w., dokładnie w 1927 r., Słowniku etymologicznym Aleksander Brückner wciąż określał etnikonimy „Bojki i Łemki” jako „nazwy nowe”" . Nowa nazwa z czasem zaczęła z powodzeniem zastępować tradycyjną nazwę Rusin, Rusnak ${ }^{20}$.

Łemkowie, których korzenie etniczne sięgają czasów kolonizacji wołosko-ruskiej, stanowią w Beskidach grupę ludności wschodniosłowiańskiej, otoczonej z trzech stron — zachodniej, północnej i południowej — ludnością zachodniosłowiańską. Są najdalej na zachód wysuniętym klinem osadnictwa wschodniosłowiańskiego. Współcześni Łemkowie na pytanie ${ }^{21}$ o swoją przynależność etniczną często odpowiadają ,,jestem Łemkiem, nazywali nas Łemkami”, nie deklarując przy tym żadnej dodatkowej przynależności narodowej:

To u nas nie mówili tam kiedyś, że to Łemek, tylko Lemko, albo mówili Rusin. To mówili tak: a to mieszkają Rusini, a tu mieszkają mieszane Lachy, a na Polaków mówili Lachy, a na nas, na Lemków, to mówili Rusini i to było taka mieszanka.

R.P., Wrocław 2012 [MM]

Najbardziej tęsknię za tymi górami, za tą dziedzicznością tam. Nikt tam się nie obrażał, ty Rusin, taki, owaki. No i co, jestem Rusin, to się nie obrażam.

J.R., Strzałkowice 1999 [AK]

Góry, Beskidy, mimo wysiedlenia Łemków pozostają wciąż ich górami. Beskidy to miejsce, w którym pozostawili swój dom. W nas doma, obok znaczenia dosłownego, oznacza 'w Beskidach, na Łemkowszczyźnie, przed wysiedleniem':

Wrocław-Poznań 1974. Zob. także M. Sopoliga, Granice i główne cechy kultury Łemków w potudniowo-wschodniej Stowacji, [w:] Lemkowie w historii..., s. 249-265.

19 Bojki, [hasło w:] A. Brückner, Stownik etymologiczny, Kraków 1927, s. 35.

20 Na południowych stokach Karpat, po stronie słowackiej zamieszkuje ludność o tym samym typie etnograficznym. Jednak tamtejsza ludność rusińska nie przyjęła nazwy Łemko, określa się jako Rusini (często z dodanym określeniem Preszowszczyzny).

${ }^{21} \mathrm{~W}$ tekście wykorzystano fragmenty wywiadów z Łemkami przeprowadzonych przez autorkę (oznaczone inicjałami MM) lub udostępnionych przez Centrum Kultury Łemkowskiej w Legnicy (wywiady przeprowadzone przez Agnieszkę Kubicę, oznaczone AK, inne oznaczone: Kycz). 


\section{Клячучы молили сме ся на голос, як дома в Болцарьові 22}

Дома бесідували по рускы, кажду неділю і свято ходили до иерккие ${ }^{23}$.

Pasmo Beskidów stanowi zamiennię łemkowskiej ojczyzny: Łemkowszczyzny. Identyfikacja terytorialna (jestem/pochodzimy/moi rodzice są z gór) pozostaje dziś jedną z ważniejszych strategii tożsamościowych Łemków:

to Abram, to może on miał nazwisko albo imię bo ja ci powiem o tam o tam u nas $\mathrm{w}$ górach to nie operowało się tak strasznie nazwiskami, tylko imionami.

/ a później byłem już traktorzystą / tak ten / bardzo cieszyłem się bo jeśli chodzi o ciągniki to ja w górach [podkr. - MM] nie widziałem ciągników /.

S.C, Strzelce Krajeńskie 2014 [MM]

\section{Materia druga — język}

[...] ścieżka kamienista / toczyło się / temkowskie stowo

[...] на пут каменистий / катурляло ся / кождое / лемківске слово $[\ldots]^{24}$

Łemkowszczyzna pod względem dialektalnym nie stanowiła nigdy jednolitego terenu.

W opinii swoich sąsiadów Łemko był „Rusinem mówiącym nieczysto po rusku”, a łemkowskie gwary postrzegane były jako „zepsuta mowa ruska”25. Język Łemków w klasyfikacjach lingwistycznych uważany jest za ukraińską gwarę zachodniokarpacką. Jej nosiciele zamieszkiwali na najdalej wysuniętym na zachód terenie Karpat. Na północy i zachodzie graniczył on z wsiami polskimi, na południu ze słowackimi, jedynie na wschodzie Łemkowie graniczyli z inną grupą ludności wschodniosłowiańskiej, Bojkami. Peryferyczne położenie w obszarze wschodniosłowiańskich dialektów ukraińskich oraz pozostawanie

22 Л. Сук, Незатерты образы, „Бесіда” 2007, nr 5, s. 17.

23 Л. Сук, Чмель. Ту останеме на долгы рокы, „Бесіда” 2008, nr 4, s. 19.

24 O. Duć-Fajfer, Ворожба / Wróżba, [w:] eadem, Po obu stronach słowa, Gorlice-Legnica 2008, s. 7.

${ }^{25}$ R. Reinfuss, Łemkowie jako grupa etnograficzna, „Prace i Materiały Etnograficzne” 7, 1948, przedruk: „Muzeum Budownictwa Ludowego w Sanoku” 1997, Sanok 1998, s. 17. 
w wielowiekowym bezpośrednim otoczeniu gwar zachodniosłowiańskich musiało mieć wpływ na ostateczny kształt językowy gwar łemkowskich. Transgresje językowe dokonywały się na wszystkich płaszczyznach systemu języka.

Zdzisław Stieber na podstawie badań terenowych prowadzonych w latach trzydziestych XX w. wyróżniał na podstawie analizy cech fonetyczno-leksykalnych Łemkowszczyznę zachodnią i wschodnią ${ }^{26}$. Wschodnia część, mniej więcej od Przełęczy Dukielskiej27, charakteryzowała się przewagą w gwarach cech typowo wschodniosłowiańskich. W gwarach zaś Łemkowszczyzny zachodniej, zwanej również właściwą lub rdzenną, obserwowano swoiste zagęszczenie cech językowych będących wynikiem transgresji zachodniosłowiańskich cech językowych. Jedną z nich jest paroksytoniczny akcent wyrazowy. Ten typ akcentu uważany jest za najbardziej wyrazistą cechę językową łemkowszczyzny. Niewątpliwie utrwalił się on pod wpływem gwar polskich i słowackich. Łemkowski akcent na przedostatniej sylabie stanowił opozycję do ogólnoukraińskiego akcentu ruchomego i swobodnego. Cechą charakterystyczną łemkowszczyzny jest także udźwięczniająca fonetyka międzywyrazowa, taka, jaka występuje w polskiej wymowie krakowsko-poznańskiej:

pov'i弓̌ $m u$ 'powiedz mu'28.

U Łemków spotykana jest również typowa dla wymowy poznańsko-krakowskiej wymowa dwugłoski $\eta k$ (tylnojęzykowa realizacja spółgłoski nosowej $\eta$ w pozycji przed tylnojęzykową $k$ ). Wpływem sąsiedztwa gwar polskich tłumaczy się również występowanie na zachodzie Łemkowszczyzny miękkiej, środkowojęzykowej wymowy spółgłosek $s, \dot{s}, c$. W gwarach wschodniosłowiańskich realizowana jest wymowa zmiękczona $\left(s^{\prime}, z^{\prime}, c^{\prime}\right)$. Janusz Rieger podaje jako przykłady wymowy miękkiej realizacje następujących łemkowskich słów:

pszenyća,

krutyty śa 'kręcić się',

kysetyća 'żur na zakwasie owsianym',

pełetyća 'pasożyt koniczyny',

kwasnyća 'mały szczaw',

sim 'siedem'29.

Dzięki transgresjom leksykalnym sięgająca czasów wspólnoty prasłowiańskiej spółgłoska *g wymawiana jest z zachowaniem swojej pierwotnej wartości fonetycznej (zamiast ogólnoukraińskiej wartości h). Notuje się więc zapożyczone z języka polskiego: gadaty, gamba, gardło, pidgardl'a 'podgardle', gaći 'spodnie z płótna' itd.; z języka niemieckiego (często za pośrednictwem polskim

26 Z. Stieber, Dialekt Łemków. Fonetyka i fonologia języka polskiego, Wrocław 1982, s. 6-7.

27 Janusz Rieger zwraca uwagę, że w języku łemkowskich mieszkańców wsi położonych za Przełęczą Dukielską częściej obserwowane były cechy językowe typowe dla gwar wschodniosłowiańskich. Zob. idem, op. cit., s. 13-14.

28 Z. Stieber, op. cit., s. 96.

29 J. Rieger, op. cit., passim.

Góry, Literatura, Kultura 11, 2018

(C) for this edition by CNS 
lub słowackim): ganok, tragaty, grul'i 'ziemniaki', morgy, gmina itd.; z języka węgierskiego: gazda, gazdyńia 'gospodyni'; z języka rumuńskiego: rumegati 'przeżuwać', $k l$ 'ak - kl'agu 'podpuszczka z żołądków cielęcych używana do wyrobu sera'.

Tendencja do zastępowania w wymowie wschodniosłowiańskiej głoski $t$ (o artykulacji przedniojęzykowej odpowiadającej wymowie polskiego tzw. $t$ scenicznego czy $\ell$ kresowego) przez polskie un niesylabiczne, opisana w Dialekcie Łemków przez Zdzisława Stiebera, obejmowała cały obszar Łemkowszczyzny ${ }^{30}$.

Cechą charakterystyczną gwar peryferycznych, do których należy gwara łemkowska, jest to, że przechowują one archaiczne elementy językowe. Jedynie w zachodniokarpackiej gwarze Łemków występuje kontynuacja prasłowiańskiej wymowy tylnojęzykowej samogłoski * $y^{31}$. Jarosław Horoszczak, autor Stownika polsko-temkowskiego/temkowsko-polskiego, we Wstępie pisze, że

„b” — jest to tzw, „," tylne, nieznane w żadnym innym języku wschodniosłowiańskim, ani w polskim. Spotykana czasem, najczęściej u innej opcji narodowej [=ukraińskiej] próba zmiany na „и” zmienia zupełnie znaczenie niektórych słów: pysk — pыsk 'pisk — pysk', byty — bыty 'bić — być', myła - mыła 'miła — myła'32.

Wymowa prasłowiańskiej samogłoski stała się zatem współcześnie dla niektórych przedstawicieli mniejszości cechą językową ich łemkowskiej odrębności etnicznej. Niemniej jednak jest to cecha ulegająca zanikowi. Już w okresie dwudziestolecia międzywojennego notowano w okolicach Sanoka formy z y wymawianym jak w języku polskim ${ }^{33}$.

W zasobie leksykalnym łemkowszczyzny obok, co oczywiste, zapożyczeń polskich i słowackich mamy liczne przykłady hungaryzmów i rumunizmów. Przy czym te ostatnie należy rozumieć w tym wypadku bardzo szeroko jako zapożyczenia leksykalne, które trafiały do gwar górali karpackich nie tylko bezpośrednio z języka rumuńskiego, lecz także za jego pośrednictwem. Będą to zapożyczenia $\mathrm{z}$ języków południowosłowiańskich, albańskie czy rumuńskie ${ }^{34}$. Leksyka ta związana jest przede wszystkim z tematyką pasterską i stanowi w dużej części (szczególnie w odniesieniu do rumunizmów) dziedzictwo po okresie wędrówek pasterzy wołoskich. Jakkolwiek należy pamiętać, że nie mówimy w tym przypadku o jakimś szczególnym i charakterystycznym zasobie leksykalnym, właściwym tylko gwarom łemkowskim. Słownictwo pasterskie zaczerpnięte z języka rumuńskie-

30 Według Riegera dziś to wymowa ,u” jest coraz powszechniejsza, zwłaszcza w przypadku najmłodszych generacji Łemków - J. Rieger, Становиско і зріжицюваня , русинскых” діалектів в Kapnamax, [w:] Русиньскый язык, red. R. Magocsi, Opole 2004, s. 65.

31 Językoznawcy dla jej oznaczenia w zapisie fonetycznym używają często grafemu „ы” Z. Stieber, op. cit., s. 10.

32 J. Horoszczak, Словник лемківско-польскій/польско-лемківскій [Stownik temkowsko-polski/polsko- temkowski], Warszawa 2004, s. 15.

33 Z. Stieber, op. cit., s. 31.

34 Zob. J. Rieger, Stownictwo i nazewnictwo..., s. 25. 
go czy węgierskiego występowało w gwarach wszystkich grup górali karpackich, zarówno wschodniosłowiańskich (bojkowskich, huculskich), jak i zachodniosłowiańskich (polskich, słowackich). Stanowi ono najlepszy przykład transgresji przekraczania granic jednego języka i przenikania w inne. W górach juhasi (węg.) zawsze mieszkali w kolibie (rum. 'szopa, prymitywne schronienie'), a owce doili w koszarze (rum. 'rodzaj przenośnego ogrodzenia'). Owca mogła być kornuta (rum. 'z zakrzywionymi rogami'), szuta (rum. 'pozbawiona rogów') albo tarkasta (rum. 'biała w czarne łatki lub czarna w białe'). Po wydojeniu juhasi przepędzali owce przez strungę (rum. 'bramkę') z jednej części koszaru do drugiej. Czasem źródło pochodzenia wyrazu jest bardzo egzotyczne, jak w wypadku watry oznaczającej 'ognisko' albo 'dno pieca, na którym kładzie się chleb do pieczenia'35. Dla Aleksandra Brücknera wyraz ten znany „,na Podhalu od pastuszków wołoskich; od nich (?) jest i u Serbów i Czechów, szczególniej u Słowaków i Rusi karpackiej” to ,[...] rumuńskie to, albańskie, cygańskie; wywodzą je od awest.[yjskiego — MM] ătar-, 'ogień', ind.[yjskiego - MM] atharī-"'36.

Rieger uważa, że zapożyczenia rumuńskie występujące w dialektach rusińskich w Karpatach „...' обнимают ріжны страны житя. Єст іх так дуже, же не спосіб іх вшыткых перерахувати" ${ }^{\prime \prime}$.

\section{Materia trzecia — religia}

Ruska wigilia spóźniona / jak jesienne ptaki ${ }^{38}$ Руска велия спізнена / Осінным птахом ${ }^{39}$

Wołosi pod wpływem liczniejszej grupy Rusinów przejęli od nich nie tylko gwarę, lecz także wyznanie prawosławne. Po podpisaniu unii brzeskiej w (1595/1596) i powstaniu w jej wyniku Kościoła greckokatolickiego podległego papieżowi zaczęto zmuszać prawosławnych mieszkańców Beskidów do zmiany wyznania. W XVIII w. prawie wszyscy mieszkańcy Łemkowszczyzny byli już unitami. Łemkowszczyzna stanowiła teren wpływów Kościołów obrządku wschodniego. Prawosławie rywalizowało o wiernych $\mathrm{z}$ grekokatolicyzmem. Zmiany wyznania najczęściej umotywowane były czynnikami ekonomicznymi. Raczej ubogi i ciężko pracujący na roli chłop wolał przynależność do Kościoła, który nie oczekiwał od niego żadnego, a przynajmniej minimalnego zaangażowania finansowego. Tak było w przypadku Kościoła prawosławnego finansowanego głównie przez Rosję. Łemkowie stanowili grupę ludności niezwykle konserwatywnej i przywiązanej do tradycyjnych wartości; charakteryzowani byli przez etnografów jako ludzie spokojni, nieangażujący się w działalność polityczną,

35 J. Horoszczak, op. cit., s. 29.

36 Watra, [hasło w:] A. Brückner, Stownik etymologiczny, Kraków 1927, s. 604.

37 J. Rieger, Становиско і зріжицюваня..., s. 60.

38 W. Graban, Ruska Wigilia, [w:] idem, op. cit., s. 39.

39 Ibidem, s. 20. 
skoncentrowani na swojej codzienności. Działalność księży greckokatolickich, silnie nastawiona na propagowanie ukraińskości wśród Rusinów, spotykała się więc ze sprzeciwem z ich strony, aspekt ten był też jednym $\mathrm{z}$ powodów dokonywania konwersji (czy raczej powrotu) na prawosławie. Jak zaznacza Jarosław Moklak, sympatia do prawosławia była zauważalna wśród Łemków jeszcze przed pierwszą wojną światową, nasiliła się zaś w drugiej połowie lat dwudziestych XX w. ${ }^{40}$

Łemkowie Kościoły rytu wschodniego nazywają „,swoimi”, w odróżnieniu do Kościoła łacińskiego, definiowanego jako Kościół „polski”. Ryt Kościoła (bizantyjski lub łaciński) wyznaczał i wyznacza nadal ostrą granicę etniczną. Charakterystyczne w tym kontekście są słowa Łemkini:

Ja pochodzę z Dubnego. U nas w Dubnym byli wszyscy Łemkowie, nie było [innych - MM]. W Leluchowie były Cyganie, było tam trochę i rzymokatolików, ale na Dubnym wszyscy byli same Lemkowie.

M. K., Źródła 2012 [MM]

Wiara stanowi wciąż ważny element przynależności do łemkowskiej grupy etnicznej. Bardzo wyraźnie pokazały ten fakt wyniki Narodowego Spisu Powszechnego Ludności przeprowadzonego w 2011 r. Spośród osób deklarujących przynależność do mniejszości łemkowskiej blisko 90\% wyraziło swoje przywiązanie do religii ${ }^{41}$. Co ciekawe, podział przynależności do poszczególnych katolickich Kościołów wschodnich rozkłada się w grupie łemkowskiej po połowie, czyli 36,3\% należy do Kościoła prawosławnego a 36,2\% do Kościoła katolickiego — obrządku bizantyjsko-ukraińskiego ${ }^{42}$.

\section{Materia czwarta — kultura}

Заграйте мі гушлі / Заграйте мі, баси 43

Robert Bierstedt uważa, że kultura „to wszystko, co ludzie czynią, myślą i posiadają jako członkowie społeczności" ${ }^{4}$. Kultura danej społeczności stanowi

40 J. Moklak, Łemkowszczyzna $w$ dwudziestoleciu międzywojennym. Zagadnienie polityczne i wyznaniowe, Kraków 1997, s. 30-31.

41 1,4\% populacji Łemków nie należy do żadnego wyznania, natomiast 8,4\% odmówiło odpowiedzi na pytanie o wyznanie. Zob. Struktura narodowo-etniczna, językowa $i$ wyznaniowa ludności Polski. Narodowy Spis Powszechny ludności i Mieszkań 2011, GUS 2011, oprac. G. Gudaszewski, Warszawa 2015, https://stat.gov.pl/spisy-powszechne/nsp-2011/nsp-2011-wyniki/struktura-narodowo-etniczna-jezykowa-i-wyznaniowa-ludnosci-polski-nsp-2011,22,1.html (dostęp: 12.10.2016), s. 104.

42 Ibidem, s. 106.

43 Ludowa piosenka łemkowska. Zob. Piosenki łemkowskie..., s. 35.

44 Zob. P. Sztompka, Socjologia, Kraków 2002, s. 233. 
ważny element odrębności etnicznej. Istotnym składnikiem kultury ludowej pozostaje folklor. Magdalena Bonowska definiuje go jako

sztukę słowa, która w ludzkiej pamięci utrwala to wszystko, co ma istotne znaczenie dla wszelkich grup zawodowych, koleżeńskich i innych organizujących się w ramach szeroko rozumianego społeczeństwa. Treści folkloru kształtowały się niewątpliwie pod wpływem doniosłych wydarzeń dziejowych i ich bezpośrednich skutków, które dotykały lokalną społeczność, jak i tych małych dokonujących się w życiu codziennym, bez których proces dziejowy i tak toczyłby się swoim torem ${ }^{45}$.

Folklor jest więc odbiciem transgresji kulturowych, co szczególnie wyraźnie przejawiać się musi w wypadku folkloru grup pogranicza, do których należy mniejszość łemkowska. Nie można zapominać także o roli folkloru w procesach tożsamościowych - wyrastając z tradycji, jednoczy członków danej wspólnoty, zarazem separując od innych grup. Twórczość słowna zaś oparta jest o rodzimy/ rodzinny język - dialekt. Jak pisze Mirosław Pecuch, ,pieśń jest drugim obok języka skrzydłem narodu"46.

W tradycyjnej kulturze Łemków odnajdujemy ślady kultur sąsiednich grup etnicznych. Przykładem zapożyczeń kulturowych, swoistego przenikania elementów, a więc przekraczania granic etnograficznych może być choćby ludowa muzyka łemkowska - przechowująca wpływy muzyki polskiej, słowackiej, ukraińskiej czy węgierskiej. W melodiach łatwo dają się wychwycić rytmy węgierskiego czardasza czy, choć już rzadziej, polskiego krakowiaka. Folklor łemkowski, podobnie jak dialekt, nie był jednolity dla całego obszaru Łemkowszczyzny. W zakresie pieśni daje się zauważyć zróżnicowanie linii melodycznych $\mathrm{i}$,wyodrębnić pewne odmiany [pieśni — MM] związane z terenami wschodniej, środkowej i zachodniej Łemkowszczyzny"47. Janusz Mroczek, krakowski muzykolog, wyróżnił cztery typy ludowych pieśni łemkowskich (oznaczając je kolejno jako typ A, B, C, D). Ale - co wydaje się najważniejsze - istnieje

zgodność pomiędzy nawarstwianiem się osadnictwa na terenach położonych między Popradem a Osławą, a odpowiadającym mu nawarstwieniem pieśni. i tak najstarsza warstwę reprezentuje grupa A obejmująca tereny pierwszej fali osadnictwa ruskiego, młodsza grupa B tereny późniejszego osadnictwa, najmłodsze nawarstwienie pieśni powstałe przy udziale wpływów polskich, słowackich i węgierskich, choć spotykane

${ }^{45}$ M. Bonowska, Dawny folklor okolic Trzebiatowa Regą, [w:] Trzebiatów - historia i kultura, red. W. Łysiak, Poznań 2000, s. 85. Cyt. za: M. Pecuch, Tożsamość kulturowa Łemków w zachodniej Polsce i na Ukrainie. Studium porównawcze, Gorzów Wielkopolski 2009, s. 114.

46 M. Pecuch, op. cit., s. 115.

47 J. Mroczek, Pieśni weselne Łemków po pólnocnych stronach Karpat, „Materiały Budownictwa Ludowego w Sanoku" 1970, nr 11, s. 18. 
na całym terenie, nie są równomiernie rozmieszczone. [...] grupa $\mathrm{C}$ powstała na Łemkowszczyźnie jako modyfikacja grupy $\mathrm{B}^{48}$.

Wspomniany już J. Mroczek zwracał uwagę na pewną ,zachowawczość kultury łemkowskiej”, wynikającą z geograficznego — górskiego — położenia wsi łemkowskich oraz z obcości etnograficznej w stosunku do sąsiedniej ludności polskiej i słowackiej. Dzięki owej „zachowawczości kultury" folklor łemkowski w odniesieniu do pieśni obrzędowych (np. weselnych, żniwnych, świętojańskich) zachował również wiele archaicznych elementów ${ }^{49}$. Najsilniejsze transgresje kulturowe, polsko-łemkowskie i słowacko-łemkowskie, w wypadku pieśni ludowej występowały na Łemkowszczyźnie zachodniej. Im bliżej wschodniej granicy ziemi Łemków, tym silniej obecne były elementy wschodniosłowiańskie. Folklor łemkowski odróżniał od polskiego na przykład charakterystyczny śpiew wielogłosowy, wywodzący się z pieśni cerkiewnych, a więc element typowy dla kultury wschodniosłowiańskiej. Dla porównania w folklorze polskim dominuje śpiew jednogłosowy.

Istniejące podobieństwo łemkowskich pieśni obrzędowych (np. świętojańskich) z tego typu pieśniami ludowymi na Słowacji, Węgrzech, południowo-wschodniej Polsce, na Wołyniu czy chociażby Pokuciu świadczy o wspólnym, być może sięgającym jeszcze czasów pogańskich, źródle ${ }^{50}$.

Transgresje kulturowe zaznaczyły się również w innych elementach kultury łemkowskiej, jak chociażby w budownictwie czy stroju. Łajbyk, czyli gorset w stroju kobiecym, pochodzi prawdopodobnie z kultury bałkańskiej. Zdobnictwem łemkowskie gorsety przypominały te noszone na ziemi sądeckiej. Chołośni - wełniane grube spodnie noszone przez mężczyzn - spotykane są, jak pisze K. Moszyński, na Słowacji, w Siedmiogrodzie i na Bałkanach ${ }^{51}$. Łemkowskie domy „chyże” z czterospadowym, krytym słomą dachem zostały ,zapożyczone” od polskich sąsiadów ${ }^{52}$.

R. Reinfuss zwracał uwagę, że z punktu widzenia etnograficznego najważniejszą cechą Łemkowszczyzny była przejściowość tego obszaru ${ }^{53}$. Przypomnijmy raz jeszcze, że na tym obszarze doszło do spotkania kultur różnych grup etnograficznych i etnicznych. W wyniku szerokich kontaktów kulturowych, dokonujących się między nimi w długim okresie dziejowym (rozpoczynając od pierwszej fali osadnictwa wołosko-ruskiego w XIV w.), następowały liczne i wieloaspektowe transgresje, które objęły wszystkie obszary życia wiejskiej ludności Beskidu Niskiego i Sądeckiego. W pasmach Karpat ukształtowała się nowa

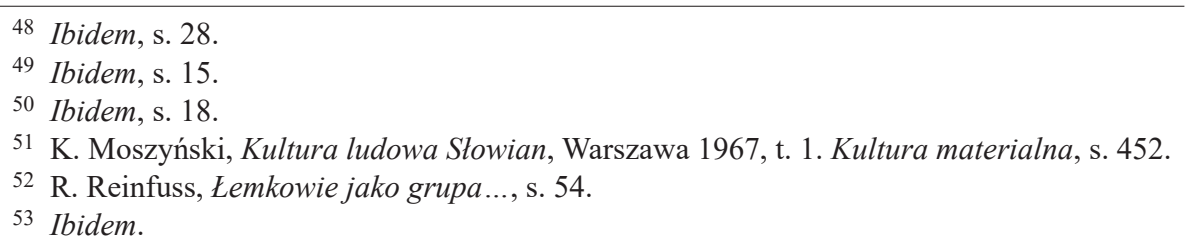


jakość — Rusini Karpaccy, po polskiej stronie nazwani Łemkami. Stoki Beskidów stały się ich „małą ojczyzną”, a identyfikacja terytorialna, werbalizowana stwierdzeniem ,jestem z gór, jestem stamtąd”, postrzegana jest współcześnie jako podstawowa strategia tożsamościowa. Związek z Beskidami dał tej społeczności poczucie jedności (,jesteśmy z Beskidów”) i odrębności wobec mieszkańców innych gór czy, co naturalne, mieszkańców nizin.

Czas, z dala od wielkiej historii, uszył w Beskidach kołpak tożsamościowy Łemków; to w Beskidach znajduje się odpowiedź na pytanie, co to znaczy być Łemkiem. Współczesna poezja łemkowska przesycona jest tęsknotą za utraconą ojczyzną/ojcowizną, pełna jest przywołań beskidzkich, „wierchów kędzierzawych, wierchów łemkowskich, kyczer zza których słońce ogrzewało młodość" i przede wszystkim Łemkowyny. Los dla Łemków nie był łaskawy. W 1947 r. bezpowrotnie utracili swój raj na ziemi. Trudno się zatem dziwić poetyckiej przenоśni - вовкы / выют / по горах / ім ся барже / повело / остали (wilki wyja po górach, im się lepiej powiodło, zostały) ${ }^{54}$.

54 S. Trochanowska, XXX, [w:] Вербина, Zjednoczenie Łemków, Warszawa 1993, s. 41. 